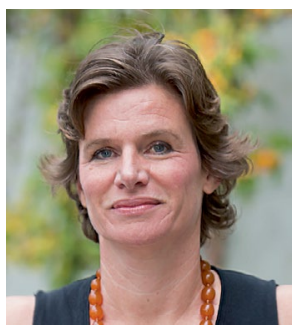

\title{
Financing the Green New Deal
}

\author{
A mission-oriented approach to transform capitalism is the only way to make progress towards \\ sustainable development, argues Mariana Mazzucato.
}

Credit: Stuart Robinson

T he sixth and most recent comprehensive report by the Intergovernmental Panel on Climate Change (IPCC) confirms that cataclysmic climate change is now "inevitable" and "irreversible" at present trajectories. The IPCC's stark warning suggests that we have only a decade to radically restructure our relationship with nature if we are to avoid the most damaging consequences of climate breakdown. The floods and fires of 2020 and 2021 are just a glimpse of what's to come. If we don't proactively overhaul finance, corporate governance and policy systems, we may face a 'climate lockdown'.

And yet the leading states of the advanced capitalist economies - those responsible for most carbon emissions, with the greatest capabilities to decarbonize - are simply not decarbonizing fast enough. Ludicrously, subsidies for fossil fuels still trump those for renewable energy. Public investment in green energy is a fraction of what it should be if we are to limit global warming to $1.5^{\circ} \mathrm{C}$.

Climate breakdown is the result of a capitalist system seeking to expand profitable extraction beyond the carrying capacity of the planet. Those ecosystemic limits were first systematically formulated in 1972 by the Club of Rome in The Limits to Growth - a seminal publication for the budding environmental movement. Now on the eve of its fiftieth anniversary, it remains shocking that so many of its insights have gone unheeded.

What is needed now is to move beyond the static debate about growth or no growth and instead focus on fundamentally redirecting development towards achieving the goal of a more inclusive and sustainable planet. We need to pivot from a reactive market-failure-fixing approach towards a proactive market-shaping one.

We are at a critical turning point. The G7 Panel on Economic Resilience, on which I sit, has recently called for a paradigm shift in global governance from the Washington Consensus to the Cornwall Consensus. Central to this is a Green New Deal. The Green New Deal repurposes the public ambition of Franklin Roosevelt's original
New Deal for the modern era; an industrial strategy for tackling climate breakdown while also generating new green jobs and ameliorating inequality. To have any chance of success, we need to radically reform and rearm the state.

Governments are the only actors capable of underwriting the scale of investments required; of coordinating multiple actors around the common goal of decarbonization; and of ensuring the costs and benefits of a green transition are distributed equitably across society so that social injustices are tackled alongside environmental crises. As I have argued before, this shift can be aided by a 'mission' oriented approach that sets key goals such as making cities carbon neutral and freeing the oceans of all plastic. Mission making begins not by asking the question 'where is the market failure that needs fixing?' but rather the question 'what is the problem we want to solve?' and then attempts to marshal economic resources across multiple sectors and coordinate diverse stakeholders around tackling this shared challenge. Mission thinking is arguably the only way we can make progress towards achieving the UN Sustainable Development Goals.

Key here is to use the full range of levers available to governments - from supply-side interventions, with the state acting as an investor of first resort (rather than lender of last resort) and as a funder and regulator with clear direction, to demand-side interventions, with the use of dynamic procurement policy to incentivize innovative solutions in domains ranging from public transport to housing. Governments play a critical role in catalysing and coordinating both public and private investment around common goals, not least transitioning to a green economy. Industrial strategies must not be about subsidizing specific sectors but about catalysing transformation across all sectors in order to meet social goals: climate action requires sectors as diverse as digital, nutrition, transport and construction to innovate and collaborate.
In terms of finance, we need the huge fiscal powers of the state - powers demonstrated by successive unprecedented governmental responses to the 2008 financial crisis and COVID-19 - to be focused on the green transition. This time around we cannot just inject the system with liquidity; finance must be directed towards creating a sustainable economy changing old industries such as steel and cement, and investing in green technologies and renewable energy. This must occur through an aligned set of policies and a range of mechanisms including innovation agencies, procurement and patient long-term finance provided through public development banks. Ambitious policies need to be structured to 'crowd in' private investors, with conditionalities attached to ensure the result is truly inclusive and sustainable.

A new social contract is required. Specifically, green conditionalities need to be built into public-private partnerships, public procurement contracts and bailout deals. A good example of the state taking the initiative and leading the green economy agenda is Germany's state-owned development bank, KfW, which offers loans to the steel industry that include conditions to reduce carbon content and emissions. The French and Dutch governments' COVID-19 bailouts for their national airline carriers, Air France and KLM, were made conditional on planes reducing emissions per passenger and cutting domestic flights in favour of rail travel - by $40 \%$ in France. But such one-off deals need to be rolled out across multiple markets - they should be normalized in both good times and bad. New metrics that measure commitments to decarbonization need to be internalized into markets so that investors and regulators can mandate companies to report the price of carbon they assume in their strategic planning. Shareholder value just doesn't cut it anymore.

The Green New Deal needs to radically transform capitalism - if it is to be saved 
from itself, and us from it. The only way to do this is through reorienting the economy around mission thinking. This means redesigning financial systems, public-private partnerships and public policy to align with the Sustainable Development Goals. Only then will we build a more innovative, sustainable and resilient economy, capable of meeting the climate challenge, rather than reacting to one crisis after another.

Mariana Mazzucato $\bowtie$

UCL Institute for Innovation \& Public Purpose,
University College London, London, UK.

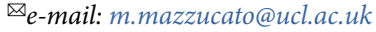

ㄱ Published online: 9 December 2021 https://doi.org/10.1038/s41893-021-00828-x

Competing interests

The author declares no competing interests. 